\title{
TOXICITY OF FOUR PESTICIDES ON EOBANIA VERMICULATA AND MONACHA OBSTRUCTA LAND SNAILS USING LEAF DIPPING AND POISON BAIT TECHNIQUE UNDER LABORATORY CONDITIONS
}

\author{
G. H. Rady(1), A. A. Asran (2), H.M. Abdelnabby(1) and M. A. Elsawaf(2) \\ (1) Plant Protection Department, Faculty of Agriculture, Benha University \\ (2) Plant Protection Research Institute, Dokki, Giza, Egypt
}

Received: Aug. 6, 2017

Accepted: Jan. 8,2018

ABSTRACT: The toxicity effect of four pesticides (Neomyl, Gastrotox, Round up and Topsin) were evaluated against the brown garden snail, Eobania vermiculata and the glassy clover snail, Monacha obstructa land snails using leaf dipping and poison bait technique under laboratory conditions.

The toxicological studies on Eobania vermiculata snail by poison bait technique reaveled that Gastrotox exibited the highest toxic effect followed by Neomyl and Round up. While, Topsin gave the least effect in this respect. Their $L C 50$ values were $(0.16,0.31,1.25$ and $2.03 \%$ ), respectively. The relative potency of Gastrotox was $0.19,0.56$ and 0.59 times than of Topsin, Neomyl and Round up and the slope values were 1.97, 1.69, 1.64 and 2.4, respectively.

On the other hand, the activity of the same tested chemicals against Monacha obstructa and the same technique showed that Gastrotox was the most potent one followed by Neomyl, Round up and Topsin. Their LC50 values were (0.18, 0.33, 1.48 and $2.48 \%$ ), respectively. Also, it noticed that the relative potency of Gastrotox was $0.37,0.56$ and 0.81 times than of Topsin, Neomyl and Round up and the slope values were 1.7, 1.72, 1.59 and 1.86, respectively.

The molluscicidal activity of Neomyl, Topsin and Round up using dipping technique against Eobania vermiculata illustrated that Neomyl exibited the highest toxic effect followed by Round up. While, Topsin gave the least effect in this respect. Their LC50 values were $0.24,0.98$ and 1.71 and the relative potency of Neomyl was 0.98 and 1.71 times than of Round up and Topsin. Also, the slope values were 0.58, 0.42 and 0.056 , respectively.

Concerning the activity of the previous tested chemicals against Monacha obstructa results indicated that Round up was the most potent one followed by Neomyl. But, Topsin gave the least effect and their LC50 values were $0.23,0.26$ and 2.23 , respectively. The relative potency of Round up was 0.52 and 0.20 times than of Neomyl and Topsin. Also, the slope values were 1.71, 1.87 and 1.83, respectively.

Key words: Brown garden snail, glassy clover snail, molluscicide, control

\section{INTRODUCTION}

Nowadays, the terresterial snails have become a destructive agricultural pests becouse it attacking many plants at their different growth stages and feed on leaves, roots, flowers and fruits causing a great economic damage to a wide varities of field crops, vegetables, horticultural plants and fruit trees in the most areas of Egypt and reduce the yield and its marketing value.

Most molluscicides against terresterial gastropods more usually deployed in baits Barker (2002). Bait technique is more suitable for reducing environmental pollution as well as the simplety for use and usually low costly. 
G. H. H. Rady, et al.,

The present work aims to evaluate the molluscicidal activity of four pesticides against two land snails species, the brown garden snail, Eobania vermiculata and the glassy clover snail, Monacha obstructa using two methods of application.

\section{MATERIALS AND METHODS}

Experiments were designed to study the control measures which can be used effectively to diminish population density and consequently damage caused by common land snails, E. vermiculata and M. obstructa.

\section{-Tested snails:}

The tested snails were adult individuals of glassy clover snails, M.obstructa (muller) and brown garden snails, E. vermiculata (muller) were collected from infested horticulture, vegetables and field crops at Ashmoon district, menufiya governorate

The snails transferred in closed bags to the laboratory and were keptseparately each species-at room temperature in glassy terrariums $(40 * 25 * 20 \mathrm{~cm})$ containing moist soil and provided with fresh green lettuce leaves for two weeks for acclimatization before testing (Godan,1983). Ten healthy individuals were selected for each replicate and starved for $\mathbf{2 4}$ hours before starting the testes.

\section{-Tested materials:}

Four pesticides belonging to different chemical groups were tested, common name, trade name and chemical name of these compounds were as follows:

-Methomyl (Neomyl 90\% WP) insecticide, molluscicide.

Chemical name:

S-methyl-N-[(methyl carbamoy)oxy] thio acetimidate.

\footnotetext{
$\begin{array}{llll}\text {-Metaldhyde } & \text { (Gastrotox } & 5 \% & \text { RB) }\end{array}$ molluscicide.
}

Chemical name:

$$
2,4,6,8
$$

tetraoxacyclooctane;

tetramethyl-1,3,5,7

tetramer

-Round up $48 \%$ WSC Herbicide

Chemical name:

$\mathrm{N}$-(phosphono methyl) glycine, iso propyl ammonium.

-Topsin 70\% WP Fungicide, Nematicide.

Chemical name:

Dimethyl [(1,2-phenylene) bis(iminocarbonothioyl)] bis [carbamate].

\section{-Procedure conducted:}

Sixty plastic boxes of $13 \mathrm{~cm}$ diameter and $15 \mathrm{~cm}$ depth were prepared to conduct the experiments by putting 10 snail in it to treat it with different pesticides. Twenty boxes, 4 replicates for each treatment, two methods were used for test these pesticides.

\section{- Method of pesticide applications:} 1-Leaf dipping technique:

Neomyl 90\%, Gastrotox 5\%, Topsin 70 $\%$ WP and Round up $48 \%$ WSC were tested at different concentrations, similar pieces of green lettuce leaves were dipped in glass jar containing $100 \mathrm{ml}$ of tested pesticide for 5 seconds, then left to dry before being offered to the tested animals. Ten adult individuals with the same shell diameter were exposed to each treated leaves in plastic box and the boxes were covered with muslin cloth held by rubber band to prevent animals from escaping, (Baker and Hawake., 1991). Each concentration was included 4 replicates and 4 replicates were kept without treatment as control. All boxes were examined after $3,6,9$ and 11 days to recorded the mortality percentage.

\section{2-Poisonous baits technique;}

Neomyl 90\%, Gastrotox 5\%, Topsin $70 \%$ WP and Round up $48 \%$ WSC were tested as poisonous baits at different concentrations, the poisonous baits were 
prepared by mixing a known of each compound with 5 parts of black sugarcane syrup, then the mixture was incorporated with wheat bran to be finally 100 parts and the bait was moistened with appropriate amount of water

Ten adult individuals were exposed to 20 grams bait in plastic box and a small piece of sponge saturated with water was kept in the bottom of each box as source of humidity to keep animals active. Boxes were covered with tiny holes muslin for ventilation and to prevent snails from escaping, 4 replicates were used for each concentration of bait and 4 replicates were prepared using wheat brain bait mixed with black sugarcane syrup only without pesticide as control. Finally, all boxes were examined after 3, 6, 9 and 11 days, the mortality percentage was calculated and recorded.

- Toxicity of the tested compounds :

Mortality percentages were calculated and corrected according to abbott's formula (1925) as follows:

Corrected mortality $=$

Observed M. \% - control M. \%

100 - control mortality\%

The toxicity lines were statistically analyzed according to Litchfield and Wilcoxon (1949) as follows:

$Y=a+b x$ were $Y=$ Probit unit, $a=$ constant value,$\quad b=$ slope of line and $\mathrm{x}=\log$ concentration .

LC50, confidential limits, and slope for the tested pesticides were calculated according to Finny (1952).

\section{RESULTS AND DISCUSSION}

A serial of experiments had been conducted to evaluate the efficiency of certain pesticides and molluscicides against adults of Monacha obstructa and Eobania vermiculata land snails using leaf dipping and poison bait technique under laboratory conditions.

\section{1- Poison bait technique:}

Neomyl, Gastrotox, Topsin and Round up were tested as poisonous bait against E. vermiculata in Table (1) and Figures $(1,2,3,4)$.

The results revealed that Gastrotox exhibited the highest toxic effect followed by Neomyl and Round up. While, Topsin gave the least effect in this respect. Their LC50 values were $(0.16$, $0.31,1.25$ and $2.03 \%$ ), respectively. The relative potency of Gastrotox was 0.19 , 0.56 and 0.59 times than of Topsin, Neomyl and Round up and the slope values were $1.97,1.69,1.64$ and 2.4 , respectively.

On the other hand, the activity of the same tested chemicals against $M$. obstructa in Table (2) and Figures $(1,2,3,4)$ showed that Gastrotox was the most potent one followed by Neomyl, Round up and Topsin. Their LC50 values were $(0.18,0.33,1.48$ and $2.48 \%)$, respectively. Also, it noticed that the relative potency of Gastrotox was 0.37 , 0.56 and 0.81 times than of Topsin, Neomyl and Round up and the slope values were 1.7, 1.72, 1.59 and 1.86, respectively.

\section{2-Leaf dipping technique:}

Data in Table (3) and Figures ( 1,3,4) show molluscicidal activity of Neomyl, Topsin and Round up using dipping technique against $E$. vermiculata . it is clear that Neomyl exhibited the highest toxic effect followed by Round up while Topsin gave the least effect in this respect. Their LC50 values were 0.24 , 0.98 and 1.71 and the relative potency of Neomyl was 0.98 and 1.71 times than of Round up and Topsin. Also, the slope values were $0.58,0.42$ and 0.056 , respectively. 
G. H. H. Rady, et al.,

Table (1). Molluscicidal activity of certain tested pesticides against adults of Eobania vermiculata land snail using poisonous bait technique under laboratory conditions.

\begin{tabular}{|c|c|c|c|c|c|}
\hline & & \multicolumn{2}{|c|}{ Confidence limits } & Slope and & Relative \\
\cline { 3 - 5 } Toxicant & LC $_{50}$ & Lower & Upper & variance & potency \\
\hline Neomyl 90 \% W P & 0.31 & 0.267 & 0.372 & $1.69 \pm 0.156$ & 0.569 \\
\hline Gastrotox 5\% G & 0.16 & 0.086 & 0.284 & $1.97 \pm 0.165$ & 0.004 \\
\hline $\begin{array}{c}\text { Topsin 70 \% WP } \\
\text { Round up 48 \% } \\
\text { WSC }\end{array}$ & 2.03 & 1.796 & 2.381 & $2.40 \pm 0.287$ & 0.198 \\
\hline & 1.25 & 1.051 & 1.514 & $1.64 \pm 0.156$ & 0.598 \\
\hline
\end{tabular}

Table (2). Molluscicidal activity of certain tested pesticides against adults of Monacha obstructa land snail using poisonous bait technique under laboratory conditions.

\begin{tabular}{|c|c|c|c|c|c|}
\hline \multirow{2}{*}{ Toxicant } & \multirow{2}{*}{ LC $_{50}$} & \multicolumn{2}{|c|}{ Confidence limits } & Slope and & Relative \\
\cline { 3 - 4 } & Lower & Upper & & variance & potency \\
\hline Neomyl 90 \% W P & 0.33 & 0.280 & 0.389 & $1.72 \pm 0.157$ & 0.569 \\
\hline Gastrotox 5 \% G & 0.18 & 0.157 & 0.219 & $1.70 \pm 0.155$ & 0.004 \\
\hline Topsin 70 \% WP & 2.48 & 2.078 & 3.275 & $1.86 \pm 0.273$ & 0.377 \\
\hline $\begin{array}{c}\text { Round up 48 \% } \\
\text { WSC }\end{array}$ & 1.48 & 1.237 & 1.845 & $1.59 \pm 0.158$ & 0.818 \\
\hline
\end{tabular}

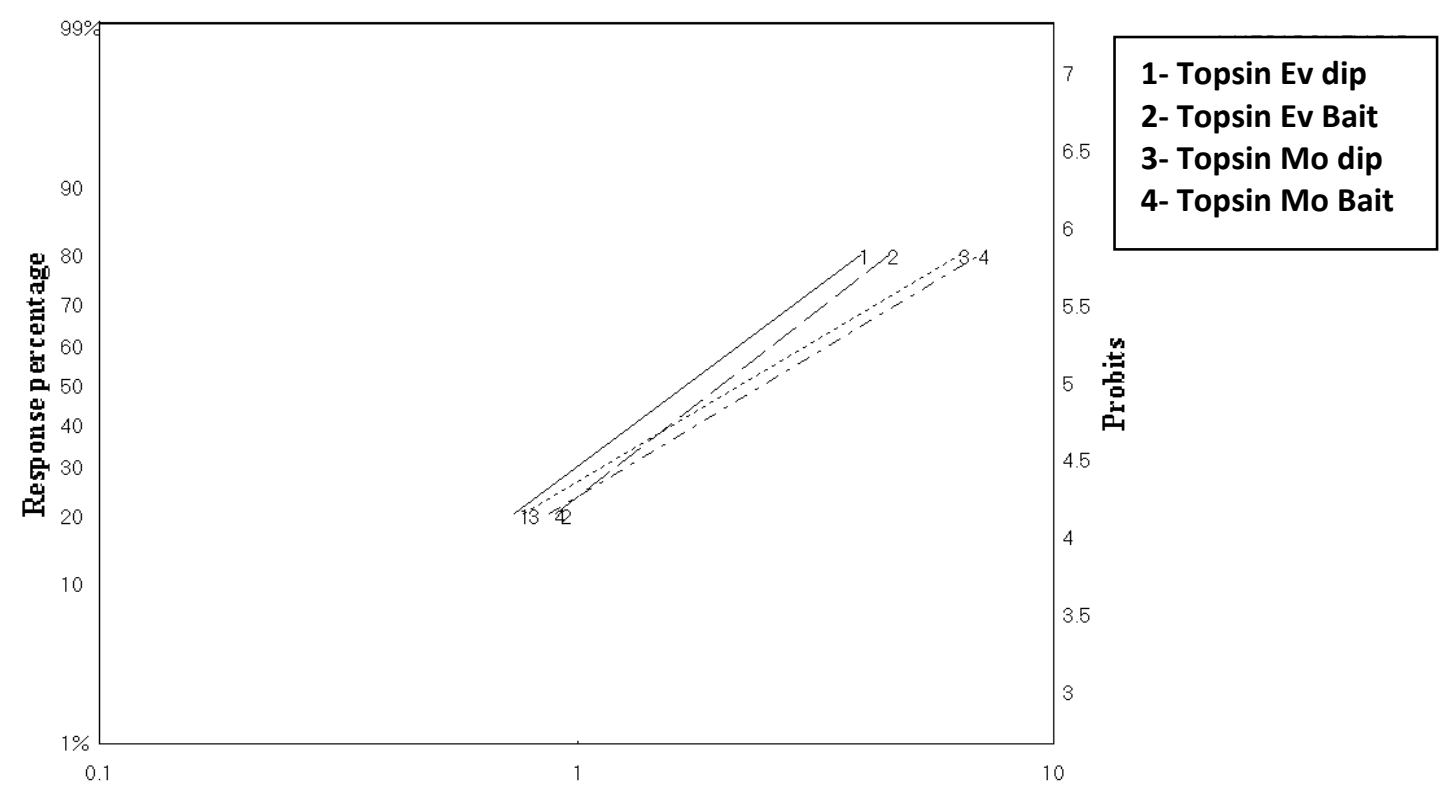

Fig. (1): LD-P lines of dipping and baiting treatments of Topsin against Monacha obstructa and Eobania vermiculata 


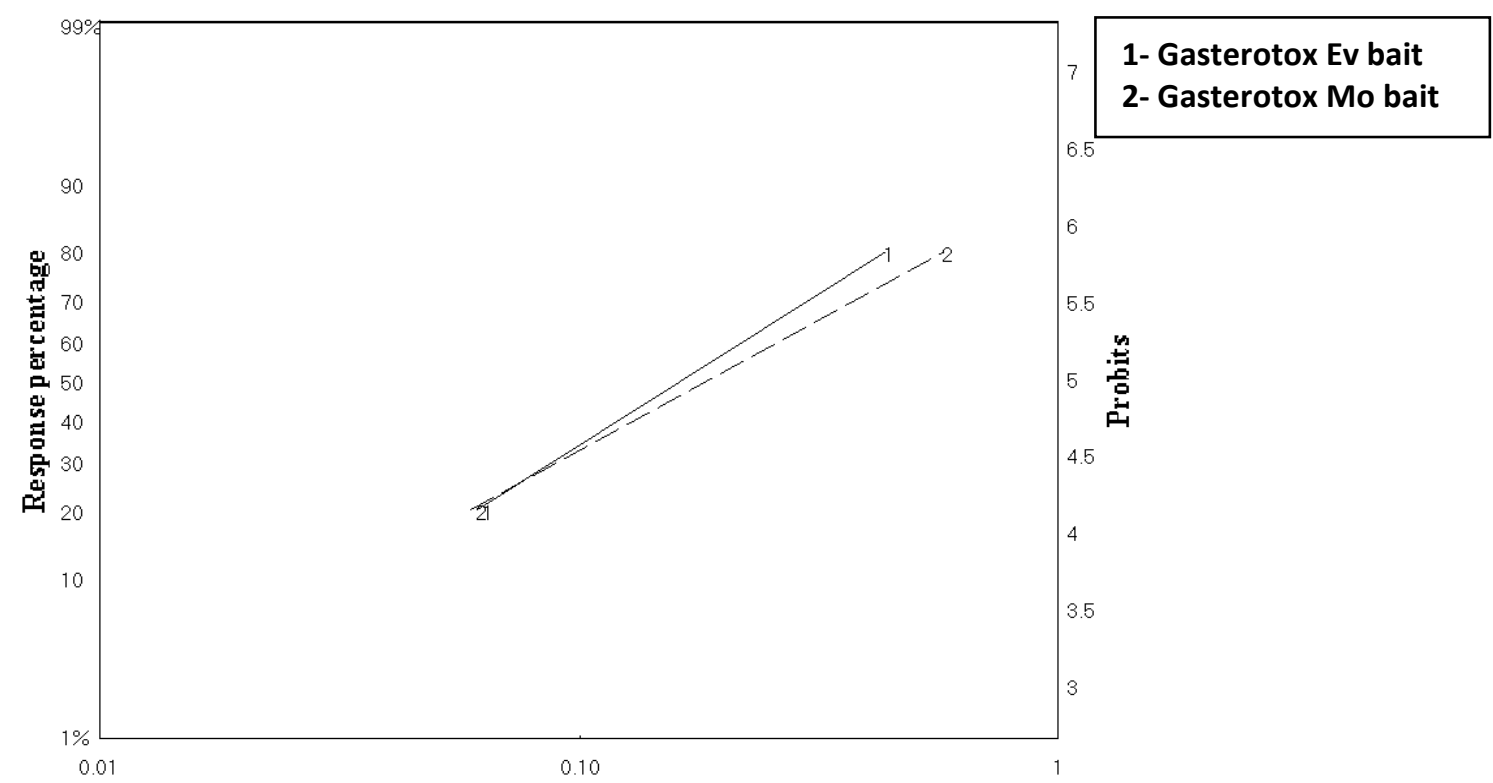

Fig. (2): LD-P lines of granules treatment of Gastrotox against Eobania vermiculata and Monacha obstructa

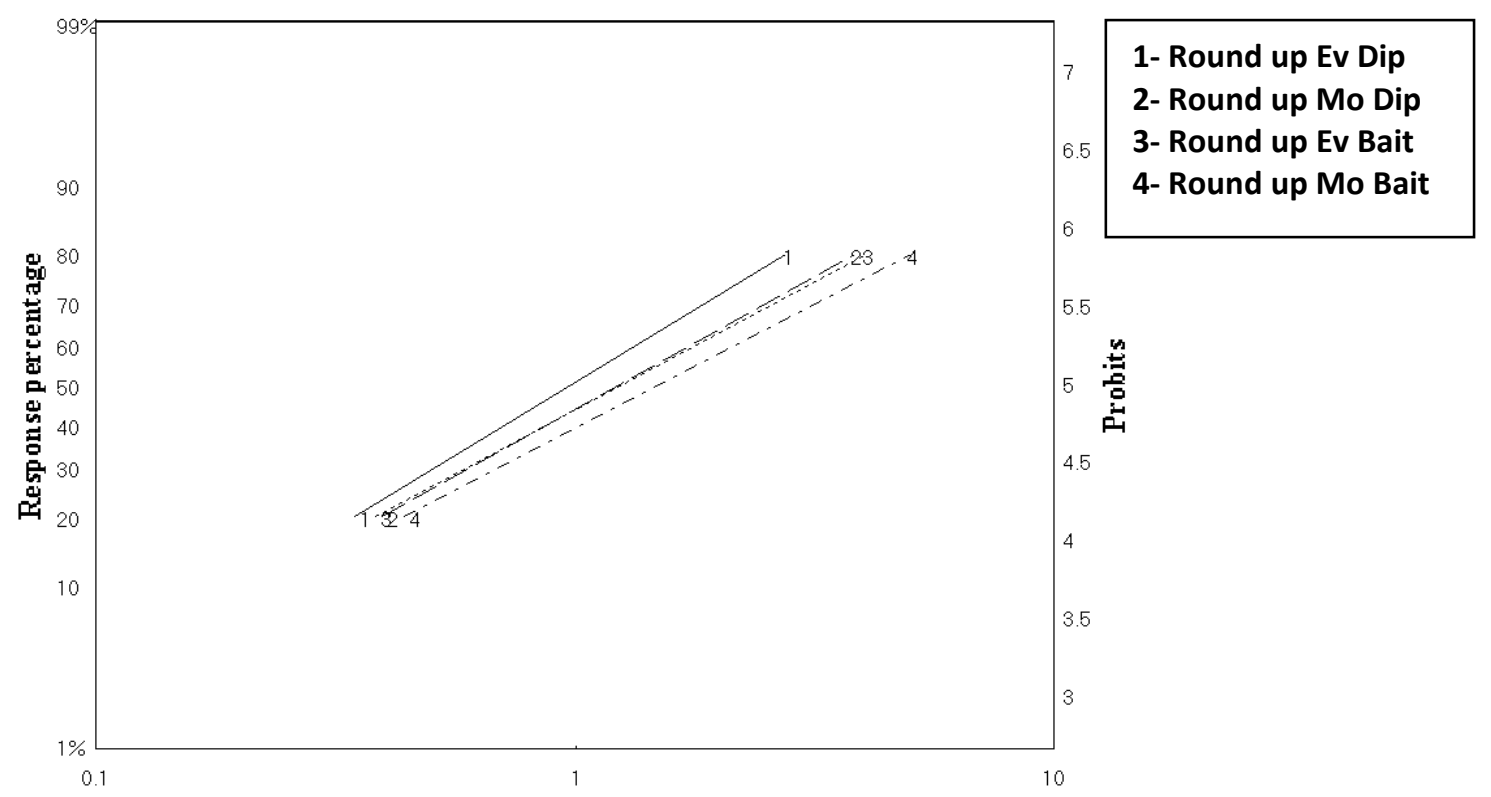

Fig. (3): LD-P lines of dipping and baiting treatments of Round up against Monacha obstructa and Eobania vermiculata. 
G. H. H. Rady, et al.,

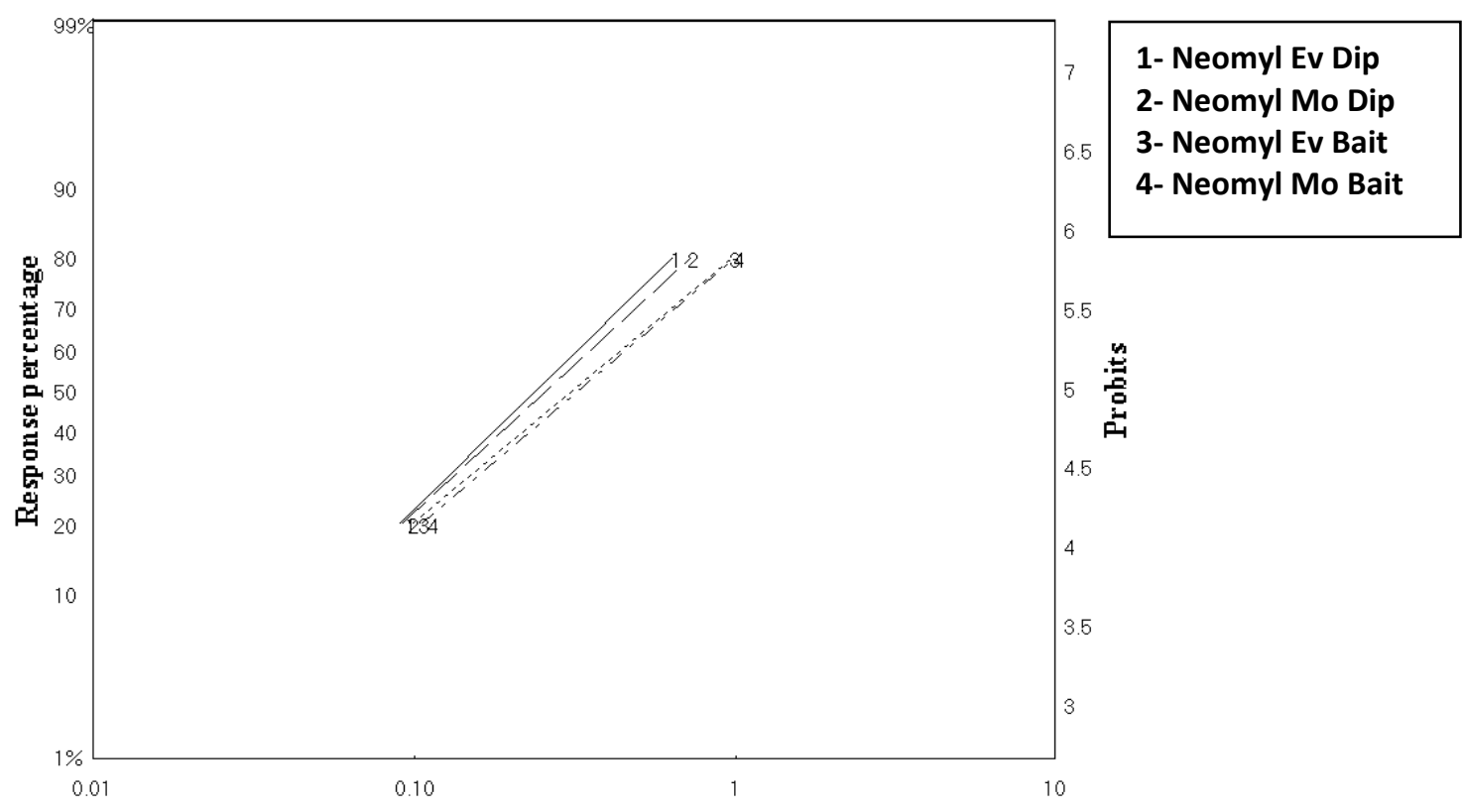

Fig. (4): LD-P lines of dipping and baiting treatments of Neomyl against Monacha obstructa and Eobania vermiculata

Table (3). Molluscicidal activity of certain tested pesticides against adults of Eobania vermiculata land snail using dipping technique under laboratory conditions.

\begin{tabular}{|c|c|c|c|c|c|}
\hline \multirow{2}{*}{ Toxicant } & \multirow{2}{*}{$\mathrm{LC}_{50}$} & \multicolumn{2}{|c|}{ Confidence limits } & \multirow{2}{*}{$\begin{array}{l}\text { Slope and } \\
\text { variance }\end{array}$} & \multirow{2}{*}{$\begin{array}{l}\text { Relative } \\
\text { potency }\end{array}$} \\
\hline & & Lower & Upper & & \\
\hline Neomyl 90 \% W P & 0.24 & 0.208 & 0.279 & $1.97 \pm 0.167$ & 0.581 \\
\hline Topsin $70 \%$ WP & 1.71 & 1.523 & 1.967 & $2.31 \pm 0.269$ & 0.056 \\
\hline $\begin{array}{c}\text { Round up } 48 \% \\
\text { WSC }\end{array}$ & 0.98 & 0.842 & 1.147 & $1.87 \pm 0.161$ & 0.416 \\
\hline
\end{tabular}

Concerning the activity of the previous tested chemicals against $M$. obstructa data in Table (4) and depicted in Figures $(1,3,4)$ results indicated that that Round up was the most potent one followed by Neomyl but Topsin gave the least effect and their LC50 values were $1.71,1.87$ and 1.83 , respectively. The relative potency of Round up was $\mathbf{0 . 5 2}$ and 0.20 times than that of Neomyl and Topsin. Also, the slope values were 1.71, 1.87 and 1.83 , respectively.
The obtained results are in agreement with those conducted by Abdel Aal (2004 and 2008), Abdel Aal and Hamed (2010), Awadalla (1997), Daoud (2010), El-Deeb et al. (1999), Essawy et al. (2009), Fouad et al. (2004), Gaber et al. (2006), Hegab et al. (2006), Mortada (2006), Mortada et al. (2005), Mortada et al. (2009) and Mortada et al. (2012), Zedan (2004), Zedan et.al. (2006) and Eshra (2014). 
Table (4). Molluscicidal activity of certain tested pesticides against adults of Monacha obstructa land snail using dipping technique under laboratory conditions.

\begin{tabular}{|c|c|c|c|c|c|}
\hline \multirow{2}{*}{ Toxicant } & & \multicolumn{2}{|c|}{ Confidence limits } & \multirow{2}{*}{$\begin{array}{c}\text { Slope and } \\
\text { variance }\end{array}$} & $\begin{array}{c}\text { Relative } \\
\text { potency }\end{array}$ \\
\cline { 3 - 4 } & LC $_{50}$ & Lower & Upper & $0.87 \pm 0.162$ & 0.525 \\
\hline Neomyl 90 \% W P & 0.26 & 0.223 & 0.304 & 1.87 & 0.204 \\
\hline Topsin 70 \% WP & 2.23 & 1.890 & 2.849 & $1.83 \pm 0.265$ & 0.827 \\
\hline $\begin{array}{c}\text { Round up 48 \% } \\
\text { WSC }\end{array}$ & 0.23 & 1.045 & 1.484 & $1.71 \pm 0.159$ & \\
\hline
\end{tabular}

\section{REFERANCES}

Abbot, W. S. (1925). A method computing the effectiveness of an insecticide. Econ. Entomol. 18: 265 -267.

Abdel Aal, S.M. (2004). Toxicity and biochemical response of Eobania vermiculata land snail to niclosamide molluscicide under laboratory and filed conditions. J. Agric. Sci. Mansoura Univ., 29(8): 4751- 4756.

Abdel Aal, S. M. (2008). Ecological, biological and control studies on certain land snails species in Sharkiah Governorate. Ph. D Thesis, Fac. Agric. Zagazig Univ. Egypt.

Abdel Aal, E. M. and S. A. Hamed (2010). Controlling aspects against terrestrial snails $E$. vermiculata and $M$. cartusiana under laboratory conditions. J. Agric. Kafr El shekh Univ., 36 (4): 463- 479.

Awadalla, Y. A. (1997). Toxicological and environmental studies of some terrestrial gastropods. M. Sc. Thesis, Fac. Agric., Alexandria Univ., 137 pp.

Baker, G. H. and B. G. Hawke (1991). Fecundity of Cochlicella acuta (Muller) (Mollusca: Helicidae), in laboratory cultures. Invert. Report and Develo., 20(3): 243-247.

Barker, G. M. (2002). Molluscs as crop pests. $C A B I$ publishing, $C A B$ Intern. Walling Ford. Oxon, OX10 8D. UK.

Daoud, M. E. A. (2010). Toxicological and biological studies on some terrestrial snail and slugs in Dakahlia governorate. Ph. D. Thesis; Fac. Agric. Al Azhar Unv., Egypt.

El-Deeb, H.I., H.A. Zedan, S.M. Abdel Aal and H.L. Mohamed (1999). Toxicity and biochemical studies on the terrestrial snail Monacha contiana treated with some natural products and pesticides . Conf. of Pest Control, Mansoura , Egypt ,Sept. 1999 , 1-12

Eshra, E. H. (2014). Toxicity of methomyl, copper hydroxide and urea fertilizer on some land snails. Annals Agric. Sci. 59 (2): 281-284.

Essawy, A.E., N.E. Abdel magid, M.A. Radwan, S.S. Hmid and A.E. Hegazy (2009). Neuron pathological effect of carbamate molluscicides on the land snail, Eobania vermiculata . Cell Biology and Toxology .25(3):275-290.

Finney, D.J. (1925). Probit analysis a statistical treatment of the sigmoid response curve. Cambridge Univ. press, 318pp.

Fouad, M. M., F. K. Khidr and T. M. Soliman (2004). Laboratory studies on the molluscicidal effect of sumithion, bindiocarb and machete pesticides against three land snail species. J. Agric. Sci. Mansoura Univ., 29(1): 451455.

Gabr, W., A. S. youssef and Fatma K. Khidr (2006). Molluscicidal effect of certain compunds against two land snail species, $M$. obstructa and $E$. vermiculata under laboratory 
G. H. H. Rady, et al.,

conditions. Egypt. J. Agric. Res. , 84 (1).

Hegab, A.M., S.A. El-Massry and W. G. Ghatwary (2006). Evaluation of certain pesticides and some plant dry leaf powder against Monacha cartusiana. Egypt. J. of Appl. Sci., 21(1) : 287- 296.

Litchfield, J. T. and F. Wilcoxon (1949). A simplified method of evaluating dose effect experiments.J.Pharmacol. Exp. Therap., (96): 99-113.

Mortada, M. (2006). Formulation and evaluation of methomyl as molluscicide against Monacha cartusiana under laboratory conditions. J. Agric. Sci. Mansoura Univ. 31(12):8027- 8033.

Mortada, M.M., T.M. Soliman and Fatma K. Khidr (2005). Molluscicidal activity of certain compounds against Monacha cartusiana land snails under laboratory and field conditions. J. Agric. Sci. Mansoura Univ., 30 (12) ; 8147-8151.
Mortada, M.M., M.M. Ahmad and M. E. Daoud (2009). Effect of methomyl on certain enzyme system in some land snails and slugs. J. Agric. Sci. Mansoura, Univ., 34(9): 9739-9745.

Mortada, M.M., A.A. M. Mourad, A. M. Abou hashim and T.M. S. Keshta (2012). efficiency of certain biocides and molluscicides against monacha species land snails at Dakahlia Governorate. J. Plant Prot. and Path., Mansoura Univ., 3(7): 717- 723.

Zedan, H.A. (2004). Fungicidal activity of metarhizium anisopliae against some land snail species under laboratory conditions J. Agric. Sci. Mansoura Univ., 24: 1359- 1366.

Zedan, H. A., M. M. Mortada and Amerah A. Shoeb (2006). Assessment of molluscicidal activity of certain pesticides against two land snails under laboratory and field circumstances at Dakahliah governorate. J. Agric. Sci. Mansourah Univ., 31(6): 3957- 3962. 


\section{سمية اربعة من المبيدات على قوقع الحدائق البنى وقوقع البرسيم الزجاجى بطريقة الغمروطريقة الطعم السام تحت الظروف المعملية}

جاد حمادة راضىى(1) ، عبد الموجود عبد الله عسران(2) ، حازم محمد عبد النبى(1) ،

ماهر عبد العزيز الصواف(2)

$$
\text { (1) قسم وقاية النبات - كلية الزراعة ، جامعة بنها }
$$

(2) معهد بحوث وقاية النباتات ، مركز البحوث الزراعية الزراعة جاتعة باتية

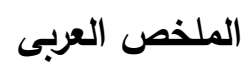

أجريت هذه الاراسة بمعامل قسم وقاية النبات بكلية الزراعة جامعة بنها ومعهل بحوث وقاية النباتات - الدقى - جيزة لتقييم فعالية بعض المبيدات فى مكافحة قوقع الحائق البنى Eobania vermiculata Monacha obstructa

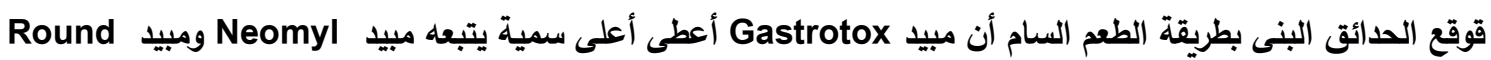

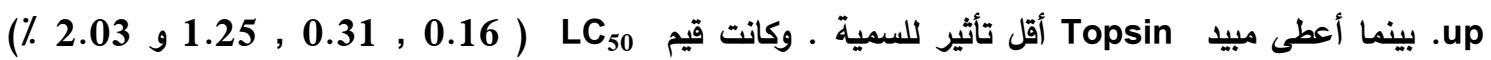

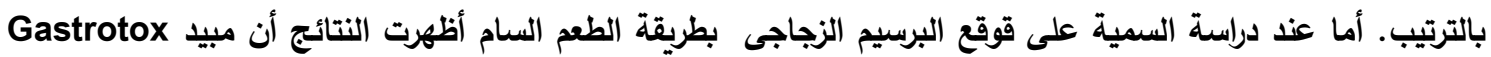

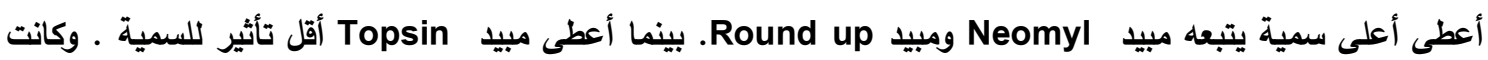
قيم LC 0.16 L $0.31,0.25$, 1.25 و 2.03 \%) بالترتيب. وبالنسبة الى قوقع الحدائق البنى بطريقة الغمر فى المبيد أظهرت النتائج أن مبيد

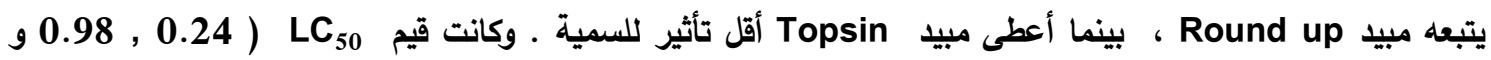
1.86 \%) بالترتيب. أما عند اجراء التجربة على قوقع البرسيم الزجاجى بطريقة الغمر فى المبيد أظهرت النتائج أن مبيد

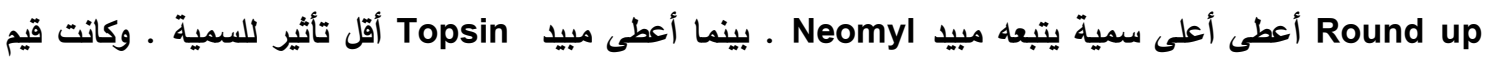

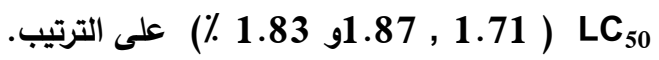

